\title{
ОДЕСЬКИЙ ПРАВОСЛАВНИЙ РУХ VS «БІЛЬШОВИЦЬКА ПРОПАГАНДА ДІЄЮ» (ПОЧАТОК 1920-х РОКІВ)
}

\author{
Микола Михайлуца ${ }^{1}$, Олександр Тригуб ${ }^{2}$ \\ 1 Одеський національний морський університет (Одеса, Україна) \\ e-mail: Michailuca@ukr.net; ORCID: https://orcid.org/0000-0003-4896-0580 \\ 2 Чорноморський національний університет імені Петра Могили (Миколаїв, Україна) \\ e-mail: alextrigub@ukr.net; ORCID: https://orcid.org/0000-0003-0610-1702
}

У науковій нарації репрезентується нарисна реконструкція православного життя в Одесі на початку 1920-х рр. на тлі комуністичного наступу у вигляді «більшовицької пропаганди дією», що знайшло реалізацію у підступних методах антирелігійної атеїстичної пропаганди, ініціюванні розколу у православній громаді міста, провокуванні у локальному релігійному соціумі міжконфесійного протистояння та інституційного самовинищення на догоду атеїстичним маніпуляторам церковного життя.

у статті зводиться окремішнє в одне ціле, й історичне, й соціальне (ментальне, релігійне, моральне, аморальне тощо), опираючись на низку законодавчих актів, невідомих/маловідомих документальних джерел, що підтверджують наступальні акції комуністів-атеїстів саме на одеському прикладі, де РПЦ була превалюючою у порівнянні з іншими церковними утвореннями і залишається такою досьогодні.

Ключові слова: Одеса, православ'я, ГПУ, церковний розкол, антирелігійна пропаганда, Жива Церква, обновленство

Проблематика церковно-релігійної історії, історії Православної церкви в Україні, попри те, що збігло вже ціле тисячоліття, й дотепер не перестає хвилювати і цікавити нинішнє православне суспільство, яке після надання томосу ПЦУ у 2019 р. ще більше «загорілося» витворенням Помісної церкви. У порівнянні з іншими науковими дискурсами на історичну тематику, сучасна релігійна - є доволі молодою та дедалі перспективною. Адже, лише наприкінці XX ст. церковна історія радянської доби, що нас особливо цікавить, отримала багатовимірний злет, сегментувалася в окремий напрямок наукових студій, проте, виглядає як далеке до завершеної повноти історіописання, якщо взагалі такого можливо досягнути в науці. Спершу такий очевидний прорив пояснюється зміною політичної парадигми в країні після розвалу тоталітарного СРСР, відкритістю вітчизняних архівів, зокрема й архівосховищ спецслужб, і, як наслідок, появою низки археографічних видань, які ввібрали в себі первинні й ексклюзивні джерела радянського періоду 1917-1991 рр., та появою обширу наукової літератури з проєкцією на різні сторони церковно-релігійного життя і державно-конфесійного протистояння.

Чи не першим дослідженням, в якому знайшли реалізацію історичні констатації й розмірковування про державу і православ'я, виявилась праця В. Пащенка, присвячена 1920-1930 рокамำ Потому, упродовж останньої чверті століття, враховуючи ши-

\footnotetext{
1 Пащенко В.О. Держава і православ'я в Україні: 20-30-ті роки XX ст. Київ: Центр пам'яткознавства АН України, 1993.
} 
роту та множинність аспектів минулого, науковий дискурс продовжили багато інших дослідників (Г.Білан, С.Білокінь, Л.Бабенко, В.Войналович, С. Жилюк, А. Зінченко, О. Ігнатуша, А. Киридон, Е.Слободянюк тощо), але кожний у своєму нішевому сегменті. Однак, так чи інакше, тема православ'я в Одесі початку 20-х років XX ст., такої непересічної на півдні України православної локації, залишилася донедавна вивченою частково. Відтак, усвідомлюючи, що саме на початку 1920-х років відбулася зміна більшовицької парадигми державно-церковних відносин, а історикиня А. Киридон, визначає саме рік 1921-й, як початок зміни курсу держави щодо релігії та церкви у вигляді широкого наступу², ставимо за мету цієї нарації репрезентувати своєрідну реконструкцію минулого через локалізацію у рамках одного міста соціально-релігійних можливостей в умовах ідеологічного пресингу комуністичної влади та підступних «практик» її органів. Маючи можливість звести окремішнє в одне ціле, історичне та соціальне (ментальне, релігійне тощо), спираючись на низку законодавчих актів, документальних джерел, що підтверджують наступальні акції комуністів-атеїстів на одеському прикладі, де РПЦ була превалюючою у порівнянні з іншими церковними утвореннями, витворимо оповідь, присвятивши її реалізації безкопромісному натиску на позиції церкви із застосуванням методів воєнного часу, який окреслила Л. Бабенко, визначаючи перший період антирелігійної кампанії: 1919 р. - поч. 1920-х рр.3

«Державна пропаганда дією»4 у практичній інтерпретації більшовицького режиму початку 20-х років ХХ ст. в межах Одеси, як і по всій УСРР, не завершилася лише пропагандою проти церкви, як духовної інституції, а перейшла в іншу, таємносилову та підступну фазу, «зіштовхуючи між собою різні напрямки, течії, секти, церкви, вірування», виснажуючи їх у взаємній боротьбі, щоби «вони дискредитували й топили один одного»5.

У вересні 1921 р. Одеський губком отримав постанову пленуму ЦК РКП(б) «Про порушення пункту 13 партійної програми і про постановку антирелігійної пропаганди»6. Відповідно 12 примірників цієї постанови було спрямовано до усіх губернських партійних структур (агітпропу, оргвідділу, контрольної комісії тощо). Постанову цю, враховуючи ї̈ відверто антирелігійну сутність, яка, до того ж, усебічно характеризує сутність комуністичної доктрини щодо релігії і церкви, втілювану на теренах контрольованих більшовиками, достеменно та прискіпливо розглянуто у вигляді опису найбільш характеристичних із одинадцяти її пунктів у нещодавно виданій книзі М. Михайлуцит.

У цьому складному, підступному, кампанійсько-наскоково-латентному процесі провідну роль узурпатори влади відводили Антирелігійній комісії при ЦК КП(б)У, яка була створена у 1922 р. та спецслужбам, зокрема ЧК-ГПУ (укр. - НК-ДПУ). Особливий статус, мета та методи роботи: репресивні, адміністративні, законодавчі, про-

\footnotetext{
2 Киридон А.М. Державно-церковні відносини в Радянській Україні (1917-1930-ті роки): зсув концептуальної парадигми. Історія релігій в Україні. Науковий щорічник. Кн. 1. Львів: Логос, 2006. C. 296.

3 Бабенко Л.Л. Радянські органи державної безпеки в системі взаємовідносин держави і православної церкви в Україні (1918 - середина 1950-х рр.). Монографія. Полтава: TOB «ACMI», 2014. С. 93.

4 Держархів Одеської області (ДАОО). Ф. 3. Оп. 1. Спр. 196. Арк. 126а-зв.

5 Ibidem.

6 ДАОО. Ф. 3. Оп. 1. Спр. 194. Арк. 14.

7 Михайлуца М.І. Православне життя в Одесі: від революції до сталінського одержавлення (19171945). Херсон: ОЛДІ-плюс, 2019. С. 69-72.
} 
пагандистсько-агітаційні, внутрішньо-конфесійні цих та інших радянських органів знайшли висвітлення у чисельних працях південно-українських істориків:

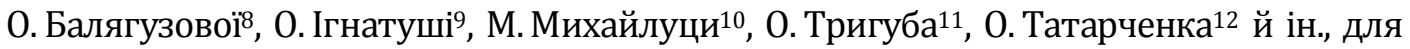
яких питання інституційного розколу в РПЦ 20-30-х років минулого століття, антирелігійної політики РКП(б)-КП(б)У, репресивного дійства спецслужб СРСР по відношенню до православних громад і православного кліру й інше стало справою наукового життя. Наше дослідницьке завдання, ставимо як одне з перших і наріжних (з погляду більшовицької влади) складових масованої атаки на релігію нарисно відтворивши технології, як саме православний рух в Одесі став іграшкою у руках спецслужб і партійних функціонерів.

Широкомасштабний наступ на «тихонівську» РПЦ уряд більшовиків розпочав 3 початку 1920-х рр., зокрема з розкольницьких проєктів щодо церкви, зформульованих одним із теоретичних розробників нищівної стратегї̈, ненависником церкви Л. Троцьким. В УСРР розкол православної церкви партійним керівництвом розпочався з серпня 1922 р., про що свідчить закритий лист секретаря ЦК Д. Лебедя, в якому вказувалося, що «у справі розколу церкви у першій половині серпня ЦК дав директиву про посилення роботи з розколу... Робота партійних і радянських організацій у напряму розколу та дискредитації неухильно продовжується, для чого й працює спеціальна комісія» ${ }^{13}$. Так звані Антирелігійні комісії, до яких входили пред-

\footnotetext{
8 Балягузова О.Ю. Розкол в українському православ'ї у 1921-1930 рр. (на матеріалах Півдня України): дис... к. іст. н.: 07.00.01. Миколаїв, 2005.

9 Ігнатуша О.М. Інституційний розкол православної церкви в Україні: ґенеза і характер (XIX ст. 30-ті pp. XX ст.). Запоріжжя: Поліграф, 2004; Ігнатуша 0.М. Радянський апарат як знаряддя боротьби проти церкви в Україні у 20-30-х pp. XX ст. // Наукові праці: Науково-методичний журнал. Т. 26. Вип. 13. Історичні науки. Миколаїв: Вид-во МДГУ ім. П. Могили, 2003. С. 92-98; Ігнатуша 0.М. До питання про становище православних конфесій на Півдні України в 20-30 pp. XX ст. (соціально-політичний аспект) // Наукові праці історичного факультету Запорізького державного університету. Запоріжжя: ДЗУ, 2000. Вип. IX. C. 98-122; Ігнатуша О.М. Вектори антицерковної політики радянської держави в Україні в 20-30-х pp. ХХ ст. // Вісник Східноукраїнського національного університету ім. Володимира Даля. 2004. № 9 (79). С. 62-69.

10 Михайлуца М.І. Православне життя в Одесі: від революції до сталінського одержавлення (19171945). Херсон: ОЛДІ-плюс, 2019; Михайлуца Н.И. Прелюдия решительного удара: борьба с православием на Юге Украины в 20-30-е гг. ХХ в. (кампании, масштабы и последствия). Проблемы истории массовых политических репрессий в СССР: 1953-2013: 60 лет без Сталина. Осмысление прошлого советского государства. Материалы VIII Международной научной конференции. Краснодар: Экоинвест, 2013. С. 178-190.

11 Тригуб О. Роль радянських органів в організації та проведенні розколу РПЦ у 1922-1925 pр. (на матеріалах Півдня України) // Релігія і церква в історії України. Збірник матеріалів Міжн. наук. конф. Полтава: ACMI, 2006. С. 435-444; Тригуб О. Діяльність регіональних антирелігійних комісій по розколу православ'я в Україні (1922-1929 рр.) // Історичні записки: Зб. наук. пр. Вип. 16. Луганськ, 2007. С. 166-175; Тригуб О. Постать Іони Атаманського в історії РПЦ на Одещині 20-х років XX ст. // «Південь України: етноісторичний, мовний, культурний та релігійний виміри». Матеріали міжн. наук.-практ. конф. (Одеса, 26 жовтня 2007 р.). Одеса: «ВМВ», 2007. С. 96-102; Тригуб О. Боротьба радянських спецслужб з церковною опозицією в Херсонсько-Одеській єпархії (1922-1923 рр.) // Південний захід. Одесика. Історико-краєзн. наук. альманах. Вип. 6. Одеса: Optimum, 2008. С. 68-85; Тригуб О. Міжконфесійна боротьба у православ'ї та ставлення віруючих Одещини до розколу Російської Православної Церкви 1920-х років // Південний захід. Одесика. Історико-краєзн. наук. альманах. Вип. 11. Одеса: Друкарський дім, 2011. С. 57-66.

12 Татарченко О.Б. Херсонська і Одеська єпархія в умовах становлення тоталітарної системи (1918-1939 рр.): дис... к. іст. н.: 07.00.01. Херсон, 2010.

13 Тригуб О. Розкол Російської православної церкви в Україні (1922-39рр.): між державним політичним управлінням та реформацією. Миколаїв: Вид-во ЧДУ імені Петра Могили, 2009. С. 155.
} 
ставники партійно-державного апарату, діяли як у центрі, так і на місцях аж до кінця 1929 р. Завдання, якими опікувалися комісії, лягали у площину організації розколу в лавах РПЦ, підриву авторитету та судилище над патріархом Тихоном, який перебував під арештом більшовиків тощо.

Поряд 3 тим, ставилося завдання організації «обновленської» церкви як інструменту розколу РПЦ на периферії, зокрема у губерніях. Особливо це стало проявлятися після утворення Всеукраїнського Вищого Церковного Управління (ВУВЦУ) обновленської церкви у Києві в лютому 1923 р. Оскільки «обновленська» церква та її осередки не користувалися де-факто великою підтримкою серед вірян, радянські спецслужби (ГПУ, НКВС) не жаліли сил і коштів на використання «обновленців» у своїй розкольницькій роботі. Тільки навесні 1923 р. ЦК КП(б)У спрямувало на потреби ГПУ 511 млн. крб. для утримання та відправки секретних співробітників на Всеросійський Церковний Собор, видання листівок, прокламацій і різних агітаційнопропагандистських видань, організацію ВУВЦУ та його передислокацію з Харкова до Києва тощо ${ }^{14}$.

Щоб зреалізувати антицерковні плани влада створювала різноманітні комісії, що діяли при губкомах КП(б)У і на 1924 р. мали вже чітку структуру на місцях. До цих комісій переважно входили партноменклатурники у губерніях і повітах, які мали назву - «трійок». В Одеській губернії така трійка була створена наприкінці серпня на початку вересня 1922 р. і складалася з представників: губкому, ГПУ та третьої особи на вибір губкому. Згідно «цілком таємного» циркуляра № 405 Одеського губкому КП(б)У, трійки повинні були складатися з «винятково витриманих і політично грамотних партпрацівників»15. Очолив цей антицерковний орган Г. Левіт - тодішній завідувач відділом агітації та пропаганди Одеського губкому партії.

Згодом трійка була розформована і її функцію по розколу православної церкви перебрала на себе Комісія по боротьбі з антирадянськими партіями та боротьбі на антирадянському фронті. Упродовж осені 1922 р. губернська «трійка» займалася справами захоплення церковної влади в Одесі й регіоні «обновленцями», поширенням поглядів і церковної платформи «обновленців», боротьбою 3 «тихонівцями», контролюванням діяльності єпископів (почасти через фабрикування кримінальних й адміністративних справ і передачею їх до суду Ревтрибуналу) тощо ${ }^{16}$.

Криза церковного життя була у постійному полі зору силових та ідеологічних органів. Сексоти повідомляли, наприклад, що діяльність Одеського кафедрального собору, зокрема богослужіння в ньому на початку 1922 р. відбувалися, але при вкрай незначній кількості віруючих у буденний час; однак у святкові ж дні - відвідування храму було вельми активним.

У політичній довідці Одеського ГубЧК від 29 січня 1922 р. подається інформація* про те, що до церковного причту Вознесіння Господнього при Воскресенській церкві

\footnotetext{
14 Центральний держархів громадських об’єднань України (ЦДАГО України). Ф.1. Оп. 20. Спр. 1772. Арк. 63-64.

15 ДАОО. Ф. П-З. Оп. 1. Спр. 390. Арк. 28.

16 Тригуб О. Роль радянських органів в організації та проведенні розколу РПЦ у 1922-1925 pp. (на матеріалах Півдня України) // Релігія і церква в історії України. Збірник матеріалів Міжн. наук. конф. Полтава: ACMI, 2006. С. 435-444; Тригуб О. Діяльність регіональних антирелігійних комісій по розколу православ'я в Україні (1922-1929 рр.) // Історичні записки: Зб. наук. пр. Вип. 16. Луганськ, 2007. С. 166-175.

* Зазначена інформація із посиланням на відомості за № 1910, подавалася чиновником не окремо, а поміж повідомленням про ситуацію на різних промислових об'єктах міста тощо.
} 
зверталося віруюче населення з проханням про проведення різного роду релігійних обрядів, хрещення і тому подібного.

Однак влада навмисно зволікала, створювала різні перепони, перш за все заплутуючи населення. Наприклад, священик, згідно з наказом Одеського губвиконкому від 4 січня 1922 р., аби провести обряд хрещення дитини, спрямовував батьків дитини до підвідділу запису актів громадянського стану, однак там (у ЗАГСі) від прохачів вимагали довідку з церкви про вінчання, хоча церковні метричні книги відповідно до того ж наказу губвиконкому було здано до губернського підвідділу ЗАГСу. Таке собі замкнене коло, яке було спрямоване проти віруючих, викликало невдоволення населення та спричиняло противладні розмови.

У першій половині лютого 1922 р. відбулось засідання Союзу приходських рад церков міста Одеси за участі представника ліквідаційної комісії по відділенню церкви від держави і школи від церкви. На цьому засіданні було актуалізовано питання викладання «Закону Божого» дітям обох статей православного віросповідання. Бажаючи вирвати свідомість підростаючого покоління із «релігійного дурману», влада стояла на тому, що право на навчання дітей істинам віри належить тільки батькам, а відтак, священнослужитель мав можливість викладати «Закон Божий» винятково особам, які досягли повноліття. Такі підходи комуністів до релігійного виховання категорично не сприймалися вірянами, що приводило до постійних порушень і зневажливого ставлення до рішень атеїстичної влади.

Розкол у середовищі одеського духівництва на початку 1922 р. був наявним і не помічати його було неможливо. Загалом перші кілька 1920-х років знаменувалися суцільними провокативними діями з боку губернської влади та більшовицьких спецслужб, які робили усе можливе, щоби знищити з середини тихонівську ієрархію РПЦ. Ставки ставились на будь-які конфесійні утворення, якби лише вони діяли у розріз з «контрреволюційною імперською тихонівською церквою».

У 1922 р., не без участі ДПУ, із числа розкольників було утворено маріонеткову групу представників «Живої церкви» (далі - «ЖЦ»), їх та приєднаних до них інших «розкольників» часто йменували «живістами». Навесні того ж року, партійними ідеологами як у Москві, так і у Харкові, за безсумнівного інсценування з боку ДПУ було знищено із середини організаційно церковну організацію РПЦ, що призвело до відтоку низової ланки парафіяльного духівництва до «живої» течії. За підтримки ідеологічних органів КП(б)У активно сприяла такого роду процесам й підвладна преса.

На півдні України «обновленство» активізується неймовірними масштабами (за винятком Херсонщини), що «приваблювало» й самі чекістські органи. Чого, власне, вони й нестерпно бажали. Володіючи інформацією про релігійний стан, органи ГПУ повідомляли Одеський губком, посилаючись на «не зовсім повні данні», що до складу групи «ЖЦ» у губернських рамках входило $542^{*}$ особи, разом з мирянами та духо-

\footnotetext{
*У книзі В. Савченка «Неофициальная Одесса эпохи нэпа (март 1921 - сентябрь 1929)» (С. 220), вкралася очевидна технічна помилка, а саме - неточне число прихильників «Живої церкви» в Одесі - 342 особи (при цьому В. Савченко посилається на статтю О. Тригуба «Боротьба радянських спецслужб з церковною опозицією в Херсонсько-Одеській єпархії (1922-1923 рр.)»).

В архівному документі, хоча й доволі погано збереженому та слабо читабельному, який наводить М. Михайлуца у книзі «Православне життя в Одесі: від революції до сталінського одержавлення (1917-1945)... С. 87» зазначається цифра у 542 особи! Що є, на нашу думку, більш імовірним. Але останнє слово за ретельним вивченням згасаючого документу.
} 
венством у кількості - 167 осіб17. Ця група останнім часом зросла; в Одесі міське духовенство та миряни щоденно записуються у групи, теж саме спостерігалося й у повітах ${ }^{18}$. Проте, у телеграмі до Харкова від 22 вересня 1922 р. одеські партчиновники зазначали, що «у всіх колах одеського духівництва царить невизначенність їхнього становища. Воно чекає зборів, які визначать ким бути: тихонівцями, обновленцями, автокефалістами». Влада усвідомлювала хитання у середовищі кліриків, фіксуючи безперечний дисонанс поміж архієрейством і нижчим духовенством, яке, виходячи із суті документу, «тяжіє до “Живої Церкви”, але приховує цей факт, боючись вищої ієрархії». Восени 1922 р. вийшов друком перший номер журналу «Церковное обновление», виданий тимчасовим комітетом «ЖЦ» у складі 6 осіб (де-факто журнал було відредаговано співробітником ГПУ Петровим ${ }^{19}$ ).

Активізація руху обновленців на Одещині і в місті, що посилило розкольницькі процеси в релігійному середовищі міста, розпочалася наприкінці листопада 1922 р. Саме тоді - 27 листопада, в Одесі за участі представника від Москви протоієрея Чудновцева й особоуповноваженого професора Покровського, відбулося зібрання одеського духовенства для слухання доповідей шанованих гостей, які повідомили про події розколу у Москві. При цьому проф. Покровський попередив, що у разі «якщо духовенство не змінить своєї вичікувальної політики, то він зніме з себе звання Особоуповноваженого і з Москви буде надісланий призначенець» 20.

На зборах були присутні представники двох повітів (Первомайського та Балтського), які мали визначити своє ставлення до «Живої Церкви». Професор Покровський, констатуючи велику ініціативу місцевого духовенства, зазначав: «Нас радує така зорганізованість i, водночас, достойна наполегливість провінційного духівництва. Останнє завжди і раніше на з'їзді духовенства у 1917 р. відрізнялося великим радикалізмом, ніж міське духівництво. Нам містянам, доводиться червоніти за свою відсталість. У нас до цієї пори ще не зорганізувався більш-менш сталий комітет групи «ЖЦ». Існуючий комітет не може проявляти себе більш рельєфно і визначено. Невпевненість, не співчування і навіть ворожі почуття з боку мирян - ось ті причини, які заважають невеликій групі “ЖЦ” в Одесі зробити більше...»21.

Представники «тихонівської» лінії, виступаючи на цьому з'їзді, вважали, що назва групи «ЖЦ» $є$ одіозною, і може лише завадити справі церковного оновлення, галасливо стверджуючи наступну тезу: «Називайте нас як хочете, тільки не “Живою Церквою”». Разом 3 тим, секретний агент ГПУ повідомляв про те, що інший «тихонівець», погоджуючись 3 необхідністю реформ, вказував на відсутність визначеності у догматичній частині програми місцевої групи та закликав майбутній комітет до особливої пильності й обережності 22.

У процесі боротьби за утворення «ЖЦ», державні органи робили все, щоб вбити клин між різними течіями, зокрема між «тихонівцями» і «живістами». Побутували думки про назву майбутньої церковної групи на зразок «Прогресивне духовенство», проте її потрібно було б реєструвати, відповідно створивши новий статут, вирішивши інші організаційні питання тощо. Зрештою, було прийнято менш ком-

ДАОО. Ф. П-З. Оп. 1. Спр. 584. Арк. 38.

18 Ibidem.

9 ДАОО. Ф. П-З. Оп. 1. Спр. 390. Арк. 57.

ДАОО. Ф. П-З. Оп. 1. Спр. 393. Арк. 315.

21 ДАОО. Ф. П-З. Оп. 1. Спр. 389. Арк. 91.

22 Ibidem. 
промісне рішення, запропоноване проф. Покровським. У результаті голосування було обрано церковний комітет «ЖЦ», до якого увійшло чотири представника від співчуваючих «живістам» і троє - «чужих». Те, як вчинили спецслужби далі, говорить про їх зацікавленість і підступність. Не зволікаючи, гепеушниками було «розіграно карту» з метою пошуку компрометуючого матеріалу на цих трьох «чужих» осіб, «аби у будь-який спосіб їх прибрати з єпархії».

Усвідомлюючи, що таємні агенти Одеського ГубЧК-ГПУ контролювали усі проповіді духовенства, останнє не дозволяло собі висловлювати думки про політику, а лише промовляло проповіді винятково на релігійні теми. Наративна інформація, що походила з кабінетів ОдгубЧК підкреслювала загальний морально-політичних дух віруючого населення міста:

«Проповіді у церквах носять винятково релігійний характер. Постійно закликається віруюча паства до дотримання посту, священнослужителі просять прихожан добровільно жертвувати на допомогу бідуючому причту. Про все, що відбувається, як-то: голод, допомога голодуючим, - не говориться ані слова. Газетні статті про вилучення церковних цінностей обходять мовчанням...»²3.

До того ж голод і скрута охопили і церковних служок, оскільки церковні прибутки скоротилися до мінімуму. Однак єпархіальне духовенство перебувало у більш вигідних умовах: вони роз'їжджали з іконами по приватним будинкам на запрошення, що добре оплачувалося віруючими. Число церковних шлюбів різко скоротилося, а плата за вінчання визначалася у значній грошовій розбіжності - у межах від 500 до 500 тис. крб. Проте, «у політичному відношенні все цілком спокійно. Сестринський кружок при Кафедральному соборі нічим себе не проявляв», - зазначалося у спецповідомленні ОдгубЧК24.

На весну 1923 р. в Одесі й окрузі релігійна ситуація характеризувалася продовженням розколу серед духовенства, що посилилося у зв'язку з проходженням Всеросійського церковного собору. Місцевий клір, жадібно слідкуючи за подіями на Соборі, затих і ніяких протестних дій не провадив. Значна частина духівництва, мирян і особливо інтелігенції віднеслася з недовірою до Собору, критикуючи й виявляючи загальне невдоволення на зразок: «Навіщо виявляти співчуття Леніну, коли церква відділена від держави?», «Навіщо Введенський благословляв комуністів від імені Христа, від якого комуністи відвертаються як біс від ладану?»25. Загалом постанови Собору було прийнято до виконання, за винятком питання переходу на новий стиль. Єпархіальне управління з приводу впровадження нового (Новоюліанського) стилю прийняло рішення спершу обговорити й ознайомити віруючих. Більшість церков Одеси прийняли рішення вищої інстанції спокійно, проте у Кафедральному соборі віруючі, переважно жінки, ледве не побили священника.

26 січня 1923 р. в Одесі відбулося чергове засідання групи «ЖЦ», яке позитивно вплинуло як на віруючих, так на мирян. Наслідком цього стало зростання звернень мирян до святих отців про створення парафіяльних громад, т. зв. «двадцяток» при церквах міських і окраїнних.

Обновленський рух в Одесі в середині 1923 р. перебував у такому ж стані, як і в попередні місяці, про що свідчили секретні інформдовідки органів ГПУ. Митрополит обновленський Євдоким, будучи в курсі справ про церковні перепетії в місті (але, аж

23 ДАОО. Ф. П-З. Оп. 1. Спр. 394. Арк. 85.

24 ДАОО. Ф. П-З. Оп. 1. Спр. 394. Арк. 23.

25 ДАОО. Ф. П-З. Оп. 1. Спр. 584. Арк. 105. 
ніяк не здогадувався, що у його справах органи ГПУ були ще краще обізнані!), у листі до Єпархіального управління, застерігав його від тісних контактів з емігрантами, говорячи, що вони хочуть «досягти свого колишнього балагополуччя нашими головами». При тому рекомендував емігрантам свою роботу провести їх власними головами, - «наші ж голови підуть на більш корисну роботу...»26.

Значна частина тих, хто не пристав до «ЖЦ» висловлювалися відверто: «Який сенс йти в обновленство, коли влада однаково вороже відноситься до них, як, власне, й до всякої релігії». Такі настрої серед духовенства і мирян призводили до втрати авторитету «живістів», попри їх активну роботу серед населення, проведення активної роз'яснювальної роботи тощо. Цей стан речей не задовольняв Одеське губернське ГПУ, особливо у той момент, коли слухи про «майбутню платформу» патріарха РПЦ Тихона викликали очікування у значної частини віруючих і священників, навіть у співчуваючих «обновленцям», і сіяли серед віруючих і кліру обережність щодо приєднання до обновленського руху загалом. За інформацією чекістів, по Одесі ходили слухи про те, що прибула до міста делегація робітників від Тихона з настановами дотримуватися лише «старого стилю» у церковних святах і практиках.

У серпні 1923 р. спротив «обновленським» процесам активізувався найбільш реакційною, за словами гепеушників «групою 22-х» священників, які заявили про свій вихід із групи «живістів». Їхні дії знайшли широку підтримку у протихонівськи налаштованого віруючого населення Одеси, яке почало активно протидіяти «обновленським» рішенням. Очолив спротив «обновленському» рухові протоієрей Портової церкви Св. Чудотворця Миколи Мірлікійського о. Іона Атаманський.

Напередодні свята Преображення Господнього (влітку 1923р.), коли єпископ Дмитрій оповістив, що святкування відбудеться за «новим стилем», то йому «посипались погрози з боку прихожан як у самому соборі, так і під час виходу з собору, а коли єпископ прибув на всю нощну, його спеціально очікував оскаженілий натовп, що ієрей змушений був припинити службу взагалі. Увечорі до нього прибула депутація з пропозицією приєднатися до “тихонівщини"»27.

Багато уваги у звітах очільників ГубГПУ приділялося різним моментам релігійного життя населення: наприклад, мали місце випадки оновлення ікон у Кафедральному соборі Одеси, що упродовж кількох днів хвилювало чисельних вірян; що реакційно налаштована маса одеситів розповсюджувала плітки про «Боже чудо» тощо. Навіть заради спростування чуток, локалізації збудженого натовпу та його фантазії було створено експертну комісію у складі представників влади, професури, віруючих та єпископа, проведено роз'яснювальну роботу.

Попри певну активність баптистських організацій, решта різноманітних малих церков, так званих сектантів, поступово занепадала і їхнє життя протікало доволі в'яло. Поміж окремих сект спостерігалася активна боротьба за збільшення кількості членів, за рахунок малих. Так, у липні 1923 р. саморозпустилася община євангелістів-християн. Формувалися міцні за організацією общини селян-бідняків, на зразок «Братська допомога», які жили за комуністичними принципами, нараховуючи по 20, 40, і навіть по 100 осіб 28 . Зрозуміло, що такі общини менше турбували радянські спецслужби через збіг своєрідних ідеологій.

\footnotetext{
26 Ibidem.

27 ДАОО. Ф. П-З. ОП. 1. Спр. 584. Арк. 159.

28 Ibid. Арк. 127.
} 
Вельми лицемірськи виглядає циркулярний лист центральної влади, який скорше був спричинений негативною реакцією населення республіки, а ніж розумінням кризової ситуації що склалася та необхідності зміни тактики щодо церкви і релігії. Одеська губернська влада (секретар губкому КП(б)У тов. Левіт) отримала таємного листа за № 656-с від 19 вересня 1923 р.29, в якому наголошувалося з одного боку, на «необхідності боротьби з релігійними поглядами», а з іншого, зверталась увага на потребі «уникати заходів адміністративного впливу».

Ще на початку 1923-го року, розігруючи антицерковну карту, більшовицька влада в Одесі діяла наступально і на випередження. По-перше, атеїсти готувались до проведення єпархіального з'їзду, який мав відбутися у лютому, а по-друге, робили все, і часто навіть руками «живістів», щоби ізолювати контрреволюційно налаштований тихонівський елемент від релігійних кіл, аби «не дай Боже!» не мати небажаних ексцесів під час проведення з'їзду. Довіри у губернської партійної влади до архієпископа Алексія (Баженова) не було. Оскільки він прославився невизначеністю власної позиції, вів, так би мовити, подвійну гру: з одного боку, був почесним головою місцевої групи «ЖЦ», а з іншого, листувався з відомими представниками реакційного духовенства, підбадьорюючи їх, давав настанови у цей складний час боротися й не здавати свої позицій. Разом з тим, В. Савченко вважає, що саме архієпископ Алексій був прихильний до українізації церкви ${ }^{30}$. Однак, представники-прогресисти пропонували на посаду управляючого Одеської єпархії кандидатуру архієпископа Нижегородського Євдокима**, відомого своїми прореволюційними поглядами та підтримкою радянської влади.

Про те, наскільки були обізнані гепеушники, говорить ще один факт, а саме про персону митрополита Євдокима. Наприклад, у травні 1923 р. він був заявлений потенційним учасником Другого помісного Собору, «проте запізнився і не встиг підписати документа про усунення від сану патріарха Тихона».

\footnotetext{
29 ДАОО. Ф. П-З. ОП. 1. Спр. 389. Арк. 39.

30 Савченко В.А. Указ. раб. С. 225.

** Євдоким Мещерський, в миру Василь Мещерський (1869-1935), нар. у Володимирській губернії Російської імперії. Закінчив Володимирську духовну семінарію (1890) і Московську духовну академію (1894). Був хіротонізований у сан єпископа Волоколамського 1904 р. Дуже протирічива фігура у спогадах, щоденниках і характеристиках багатьої архієреїв. Перебуваючи ректором Московської ДА, був причетний до звільнення історика В. Ключевського, характеризувався «брехливістю», скандальною поведінкою, фінансовими розтратами тощо. У листопаді 1918 р. став Нижегородським архієреєм. Декларував повну лояльність і підтримку радянській владі, зокрема й під час вилучення церковних цінностей. Звинувачував патріарха Тихона у руйнуванні церкви, підтримав обновленське Вище церковне управління (ВЦУ), виступивши з відкритим листом про солідарність з прогресивною групою духовенства. Зведений обновленцями у сан митрополита. 3 листопада 1922 р. - обновленський митрополит Одеський і Херсонський. Згідно з повідомленями ГПУ у жовтні 1923 р. за час перебування в Одесі митрополит Євдоким викликав вороже ставлення з боку широких мас віруючих, в тому числі й через його інтимні зв'язки з черницею, яку він привіз з Нижнього Новгорода. У 1923 р. призначений головою Вищої церковної ради. Був учасником 2-го обновленського помісного собору у травні 1923 р. Автор панегірика з приводу смерті В. Леніна, написавши листа М. Калініну з прославлянням вождя пролетаріату, в якому побажав «багатостраждальній, добрій і християнській душі» вождя-атеїста вічної пам'яті і вічного покою. Через низку причин, зокрема, неспроможність досягти угоди 3 патріаршою церквою про об’єднання, чого хотіла влада, через конфлікт з лідером обновленського руху О. Введенським та інше, був відсторонений більшовиками від керівництва Священного Синоду у 1925 р. Помер 1935 р., залишившись обновленцем, через кілька днів після розпуску сталіністами Священного Синоду.
} 
Знали спецслужби й про проблеми архієпископа Алексія (Баженова), «з яким перебуває у ворожнечі майже увесь єпархіальний клір». Питання стосовно моральної поведінки архієрея мало обговорюватися на з'їзді. Усі якраз і чекали моменту, щоби «зірвати архієпископа з місця». Архієпископ Алексій збирався їхати до Києва для участі в утворенні Вищого Церковного Управління (ВЦУ), до того ж, на нього був зібраний відділом ГубГПУ компрометуючий матеріал «з приводу невиконання декрету радянської влади і проведення шлюборозводних справ, за що його передбачалося притягнути до гласного суду».

Окрім суто релігійних та інституційних питань, які перебували у розробці антирелігійних органів (АРК, ГПУ), у їх полі зору перебували й питання фанансовоекономічні, якими вони підступно зловживали. Антирелігійна комісія при Одеському губкомі КП(б)У з подачі керівництва ГубГПУ, яке бачило у економічному тиску на «тихонівців» певну підтримку інтересів «обновленців» заради їх превалювання у місті, активно лобіювала наступні фіскальні питання. Так, комісія намагалася зменшити до мінімуму, а у випадках гострої потреби, зовсім знімати податки на «обновленські» приходи і їхніх церковнослужителів. I навпаки, наполегливо пропонувалося вжити заходів до можливого підвищення в м. Одесі та в інших містах податків на «тихонівців» ${ }^{31}$. Цікава гра спостерігається й у подальшому. Весною 1924 р. Одеська АРК, намагаючись максимально приховати власну вибіркову політику щодо надання преференцій «обновленцям» на противагу «тихонівцям», напосідаючи на своєму, укривала від фінансових органів справу зменшення оподаткування для «обновленців», і вимагала від вищих компетентних органів подати це таким чином, що ініціатором усього були центральні органи, які ніби пішли на поступки невдоволеному населенню.

Більшовицькі спецслужби також негласно ідеологічно спрямовували, а часом й самі організовували публікації матеріалів про обновленський рух у пресі 20-х років. Дослідник цього періоду О. Тригуб вважає, що саме в надрах ДПУ ініціювалися від імені «обновленців» статті, які друкувалися на сторінках центральних і місцевих друкованих органів. Між іншим, усі статті друкувалися анонімно, прикриваючись такими іменами як: «Обновленец», «Мирянин», «Сторонник обновления» тощо, що також підтверджує «руку ГПУ» у процесі ініціювання та популяризації розколу серед православних міста.

Отож влада, завдячуючи «ордену мечоносців-депеушників» та його агентурі, зреалізувала свої підступні плани спрямовані на розкол церковного середовища із осереддя, його ж руками, використовуючи його ж духовних лідерів, не гребуючи підкупами, прикормленням коштами, залякуванням та обіцянками надання політичних, чи економічних преференцій тій, чи іншій конфесії. Віруючий люд у черговий раз ставав орудою та матеріалом у руках політичної сили, яка своєю атеїстичною «вірою» намагалася замінити віру Христову.

\section{REFERENCES}

Babenko, L.L. (2014). Radianski orhany derzhavnoi bezpeky $v$ systemi vzaiemvidnosyn derzhavy i pravoslavnoi tserkvy v Ukraini (1918 - seredyna 1950-kh rr.) [Soviet State Security Bodies in the System of Relations Between the State and the Orthodox Church in Ukraine (1918 - mid-1950s)]. Poltava: TOV «ASMI» [in Ukrainian].

Baliahuzova, O.Yu. (2005). Rozkol v ukrainskomu pravoslav'i u 1921-1930 rr. (na materialakh Pivdnia Ukrainy) [The Schism in Ukrainian Orthodoxy in 1921-1930 (based on materials from the South of

31 Тригуб О. Розкол Російської православної церкви в Україні (1922-39 рр.)... С. 165. 
Ukraine)].(Candidate's thesis). Mykolaiv [in Ukrainian].

Ihnatusha, O.M. (2000). Do pytannia pro stanovyshche pravoslavnykh konfesii na Pivdni Ukrainy v 2030 r. XX st. (sotsialno-politychnyi aspekt) [On the Question of the Situation of Orthodox Denominations in the South of Ukraine in the 20-30s of the XX century (socio-political aspect)]. Naukovi pratsi istorychnoho fakultetu Zaporizkoho derzhavnoho universytetu (Vol. IX, pp. 98-122). Zaporizhzhia: DZU [in Ukrainian].

Ihnatusha, 0.M. (2003). Radianskyi aparat yak znariaddia borotby proty tserkvy v Ukraini u 20-30kh rr. XX st. [The Soviet Apparatus as an Instrument of Struggle Against the Church in Ukraine in the 20-30's of the XX century]. Naukovi pratsi: Naukovo-metodychnyi zhurnal (Vol. 26, Issue 13: Istorychni nauky, pp. 92-98). Mykolaiv: Vydavnytstvo MDHU im. P. Mohyly [in Ukrainian].

Ihnatusha, O.M. (2004). Vektory antytserkovnoi polityky radianskoi derzhavy v Ukraini v 20-30-kh rr. XX st. [Vectors of the Anti-Church Policy of the Soviet State in Ukraine in the 20-30s of the XX century]. Visnyk Skhidnoukrainskoho natsionalnoho universytetu imeni Volodymyra Dalia, 9 (79), 62-69 [in Ukrainian].

Ihnatusha, O.M. (2004). Instytutsiinyi rozkol pravoslavnoi tserkvy v Ukraini: geneza i kharakter (XIX st. 30-ti rr. XX st.) [Institutional Schism of the Orthodox Church in Ukraine: Genesis and Character (XIX century - 30s of the XX century)]. Zaporizhzhia: Polihraf [in Ukrainian].

Kyrydon, A.M. (2006). Derzhavno-tserkovni vidnosyny v Radianskii Ukraini (1917-1930-ti roky): zsuv kontseptualnoi paradyhmy [State-Church Relations in Soviet Ukraine (1917-1930s): a Shift in the Conceptual Paradigm]. Istoriia relihii v Ukraini. Naukovyi shchorichnyk (Vol. 1, pp. 293-302). Lviv: Lohos [in Ukrainian].

Mikhailutsa, N.I. (2013). Preliudiia reshitelnogo udara borba s pravoslaviem na Yuge Ukrainy v 20-30e gg. XX v. (kampanii, masshtaby i posledstviia) [Prelude of a Decisive Blow: the Struggle With Orthodoxy in the South of Ukraine in the 20-30s of XX century (Campaigns, Scope and Consequences)]. Abstracts of Papers: V Mezhdunarodnaia nauchnaia konferentsiia «Problemy istorii massovykh politicheskikh repressii v SSSR: 1953-2013: 60 let bez Stalina. Osmyslenie proshlogo sovetskogo gosudarstva». Krasnodar: Ekoinvest, Pp. 178-190 [in Russian].

Mykhailutsa, M.I. (2019). Pravoslavne zhyttia v Odesi: vid revoliutsii do stalinskoho oderzhavlennia (1917-1945) [Orthodox Life in Odessa: from the Revolution to Stalin's Nationalization (1917-1945)]. Kherson: OLDI-plius [in Ukrainian].

Pashchenko, V.o. (1993). Derzhava i pravoslavia v Ukraini: 20-30-ti roky XX st. [State and Orthodoxy in Ukraine: 20-30s of the XX century]. Kyiv: Tsentr pamiatkoznavstva AN Ukrainy [in Ukrainian].

Savchenko, V.A. (2012). Neofitsialnaia Odessa epokhy nepa (mart 1921 - sentiabr 1929) [Unofficial Odessa of the NEP Era (March 1921 - September 1929)]. Moskva: Rossiiskaia politicheskaia entsiklopediia (ROSSPEN) [in Russian].

Tatarchenko, O.B. (2010). Khersonska i Odeska yeparkhiia $v$ umovakh stanovlennia totalitarnoi systemy (1918-1939 rr.) [Kherson and Odessa's Eparchy in the Conditions of Formation of the Totalitarian System (1918-1939)]. (Candidate's thesis). Kherson [in Ukrainian].

Trygub, 0. (2006). Rol radianskykh orhaniv v orhanizatsii ta provedenni rozkolu RPTs u 1922-1925 rr. (na materialakh Pivdnia Ukrainy) [The Role of Soviet Bodies in the Organization and Conduct of the Schism of the ROC in 1922-1925 (on the materials of the South of Ukraine)]. Relihiia i tserkva $v$ istorii Ukrainy. Zbirnyk materialiv Mizhnarodnoi naukovoi konferentsii (pp.435-444). Poltava: ASMI [in Ukrainian].

Trygub, 0. (2007). Diialnist rehionalnykh antyrelihiinykh komisii po rozkolu pravoslavia v Ukraini (1922-1929 rr.) [Activities of Regional Anti-Religious Commissions on the Schism of Orthodoxy in Ukraine (1922-1929)]. Istorychni zapysky: Zbirnyk naukovykh prats (Vol. 16, pp. 166-175). Luhansk [in Ukrainian].

Trygub, 0. (2007). Postat Iony Atamanskoho v istorii RPTs na Odeshchyni 20-kh rokiv XX st. [The Figure of Iona Atamansky in the History of the ROC in the Odessa Region in the 1920s]. Pivden Ukrainy: etnoistorychnyi, movnyi, kulturnyi ta relihiinyi vymiry (pp. 96-102). Odesa: «VMV» [in Ukrainian].

Trygub, 0. (2008). Antyrelihiina komisiia v Ukraini (1922-1929 rr.): rehionalnyi aspekt [Anti-religious Commission in Ukraine (1922-1929): Regional Aspect]. Derzhava i Tserkva v Ukraini za radianskoi doby (pp. 147-154). Poltava: ASMI [in Ukrainian].

Trygub, 0. (2008). Borotba radianskykh spetssluzhb z tserkovnoiu opozytsiieiu v Khersonsko-Odeskii yeparkhii (1922-1923 rr.) [The Struggle of Soviet Special Services Against the Church Opposition in the Kherson-Odessa Eparchy (1922-1923)]. Pivdennyi zakhid. Odesyka. Istoryko-kraieznavchyi naukovyi almanakh (Vol. 6, pp. 68-85). Odesa: Optimum [in Ukrainian].

Trygub, 0. (2009). Rozkol Rosiiskoi pravoslavnoi tserkvy v Ukraini (1922-39 rr.): mizh derzhavnym 
politychnym upravlinniam ta reformatsiieiu [The Schism of the Russian Orthodox Church in Ukraine (1922-39): Between Public Political Administration and the Reformation]. Mykolaiv: Vyd-vo ChDU imeni Petra Mohyly [in Ukrainian].

Trygub, 0. (2011). Mizhkonfesiina borotba u pravoslavi ta stavlennia viruiuchykh Odeshchyny do rozkolu Rosiiskoi Pravoslavnoi Tserkvy 1920-kh rokiv [Inter-confessional Struggle in Orthodoxy and the Attitude of the Believers of Odessa Region to the Schism of the Russian Orthodox Church in the 1920s]. Pivdennyi zakhid. Odesyka. Istoryko-kraieznavchyi naukovyi almanakh (Vol. 11, pp. 57-66). Odesa: Drukarskyi dim [in Ukrainian].

\section{Mykola Mykhailutsa}

(Odesa national maritime university, Odesa, Ukraina)

e-mail: Michailuca@ukr.net

ORCID: https://orcid.org/0000-0003-4896-0580

\section{Oleksandr Trygub}

(Petro Mohyla Black Sea National University, Mykolaiv, Ukraine)

e-mail: alextrigub@ukr.net

ORCID: https://orcid.org/0000-0003-0610-1702

\section{Odesa Orthodox Movement vs ‘Bilshovyk Propaganda by Action’ (Early 1920s)}

A descriptive reconstruction of Orthodox life in Odesa in the early 1920s is presented against the background of the communist offensive in the form of 'Bilshovyk propaganda by action', which was realized in treacherous methods of anti-religious, atheistic propaganda, initiating a schism in the city Orthodox community, and provoking local religious opposition and institutional self-destruction in the local religious society to please atheistic manipulators of church life.

The analyzed archeographic basis of the research and professional publications of recent years have allowed the authors to reconstruct the main vector components of the communist government's policy aimed at limiting social and religious opportunities under the communist government's ideological pressure and treacherous practices.

Different notions are united in the paper, historical as well as social (mental, religious, moral, immoral, etc.), based on certain legislative acts, unknown documentary sources confirming the offensive actions of communist atheists just on the example of Odesa, where the ROC was prevalent in comparison with other church formations as it remains to this day.

Keywords: Odesa, Orthodoxy, GPU, church schism, anti-religious propaganda, Living Church, Renovationizm 